\title{
Yaşıı Bireyin Bakımında Hemşirelik Yetkinliğinin Arttırılmasına Yönelik Eğitim Yöntemleri: Sistematik Derleme
}

\section{Educational Methods for Increasing Nursing Competence in Elderly Care: A Systematic Review}

\author{
Rabia $\operatorname{Eren}^{1}$ (D), Merdiye Şendir² (D)
}

\begin{abstract}
${ }^{1}$ Medipol Üniversite Hastanesi, Hemşirelik Hizmetleri Müdürlüğü, Eğitim Gelişim Hemşireliği, İstanbul, Türkiye ${ }^{2}$ Sağlık Bilimleri Üniversitesi, Hamidiye Hemşirelik Fakültesi, Hemşirelik Esasları Anabilim Dalı, İstanbul, Türkiye
\end{abstract}

\section{ÖZET}

Amaç: $\mathrm{Bu}$ sistematik inceleme, yaşlı bireylerin bakımında hemşirelik yetkinliğinin arttırılmasına yönelik kullanılan eğitim yöntemlerinin sonuçlarını değerlendiren çalışmaları sistematik olarak incelemek amacıyla yapılmıştır.

Gereç ve Yöntemler: Çalışmanın evrenini Mart-Ekim 2020 tarihlerinde Sağlık Bilimleri Üniversitesi elektronik veri tabanlar1, "Türk Tıp Dizini”, "ULAKBİM", "Pubmed", "Google Scholar", "Science Direct", "Networked Digital Library of Theses and Dissestations" taranarak ulaş1lan 350 makale oluşturmuştur. İncelemede "simülasyon", "hemşirelik" ve "yaşlı birey" anahtar kelimeleriyle Türkçe ve İngilizce olarak son on yılda yayınlanmış (2010-2020), yayın dili Türkçe ya da İngilizce olan, tam metni bulunan makaleler seçilmiştir. Bu makalelerden araştırma kriterlerini karşılayan toplam 17 makale incelemenin örneklemini oluşturmuştur.

Bulgular: Yaşlı bireylerin bakımında hemşirelik yetkinliğinin arttırılmasına yönelik kullanılan eğitim yöntemlerine ilişkin çalışmaların sistematik incelemesinde araştırmaya dahil edilen 2 çalışmanın örneklemini klinik/çalışan hemşireler, 15 çalışmanın örneklemini ise hemşirelik öğrencileri oluşturmuştur. Klinik hemşireler ile yapılan çalışmalarda hemşirelerin yaşlı bireylere yönelik bakım kalitesinin, tutum ve istekliliklerinin arttığı saptanırken, öğrenciler ile ilgili yapılan çalışmalarda ise bilgi, beceri, tutum, farkındalık, empati, bakım motivasyonu ve klinik karar verme becerilerinin arttığı saptanmıştır.

Sonuç: Hemşirelere yönelik olarak hizmet içi eğitim programları içerisinde simülasyon temelli eğitimlerin gerçekleştirilmesi, yaşlı bireylere yönelik bakım becerilerinin ve yetkinliklerinin güçlendirilmesinde ve bakım maliyetinin en aza indirilmesinin sağlanmasında etkili olduğu görülmektedir.

Anahtar kelimeler: Hemşirelik, simülasyon, yaşlı birey

\section{ABSTRACT}

Aim: This systematic review is planned to systematically examine studies that evaluate the results of educational methods used to increase nursing competence in the care of elderly individuals.

Material and Methods: The universe of the study was reached by scanning the electronic databases of Health Sciences University, "Turkish Medical Directory", "ULAKBIM", "Pubmed", "Google Scholar", "Science Direct", "Networked Digital Library of Theses and Dissertations" between March and October 2020. Articles with the keywords "simulation", "nursing" and "elderly person", published in Turkish and English in the last ten years (2010-2020), with full text in Turkish or English, were selected in the study. A total of 17 articles from these articles meeting the research criteria constituted the sample of the review.

Results: In the systematic review of studies on educational methods used to increase nursing competence in the care of elderly individuals, the samples of 2 studies included in the study were clinical/working nurses, and the samples of 15 studies were nursing students. In studies conducted with clinical nurses, it was found that the quality of care, attitude, and willingness of nurses towards older adults increased, while studies on students found that their knowledge, skills, attitude, awareness, empathy, motivation to care, and clinical decision-making skills increased.

Conclusion: Simulation-based training within in-service training programs for nurses appears to be effective in strengthening care skills and competencies for older adults and minimizing care costs.

Keywords: Nursing, simulation, older adult

\footnotetext{
Sorumlu Yazar / Corresponding Author: Rabia Eren (iD

E-posta / E-mail: rabia.yaman@medipol.com.tr

Adres / Address: Medipol Üniversite Hastanesi, Hemşirelik Hizmetleri Müdürlüğü, Eğitim Gelişim Hemşireliği, Bağcılar, İstanbul, Türkiye

Telefon / Phone: +90 5302418543

Geliş Tarihi / Received: 09.01.2021 Kabul Tarihi / Accepted: 19.04.2021
} 


\section{GÍRİŞ}

Yaşl11ık, engellenmesi mümkün olmayan, fonksiyonlarda azalmayla birlikte bakım gereksiniminin arttığ1, toplumun kültürel değerleri ve geniş aile yapısının değişmesi sonucu kayıpların ortaya çıktığı, organizmanın denge kurma potansiyelinin azaldığı ve sosyal sorunların ortaya çıktığı bir dönemdir $(1,2,3)$. Dünya'da, 60 yaş ve üzeri nüfusun 2017 yılında 962 milyon olduğu, 2050 yılına gelindiğinde bu sayının ikiye katlayarak 2,1 milyar olacağı, ülkemizde de 2050 yılına gelindiğinde 65 yaş ve üzeri bireylerin toplam nüfus içindeki oranının $\% 20,2$ olacağı ön görülmektedir $(4,5,6,7)$.

Dünyada yaşam süresinin uzaması ve doğum oranlarının düşmesi ile birlikte gerçekleşen demografik değişim sürecinde, yaşlı bakımı ile ilgili sorunlar gündeme gelmekte dolayisıyla sağlık kurum ve kuruluşlarının yaşlanma ve yaşlı sağlığına yönelik politikalar geliştirmesi gerekmektedir $(8,9)$.

Dünyadaki demografik değişim dikkate alındığında, sağlık hizmetinin gerçekleştirildiği hastanelerde yaşlıların bakım gereksinimini anlayan, yaşlı bakım ve rehabilitasyonunu planlayan, sağlığın korunması ve geliştirilmesi için mevcut fonksiyon düzeyinin devamlılığını sağlayan, bireyi fiziksel, psikolojik, sosyal ve kültürel bir bütün olarak değerlendiren yetkin hemşirelerin yetiştirilmesi gerekmektedir $(10,11)$.

Hemşirelik uygulama alanında iyi planlanmış bir hizmet içi eğitim programı, bakım standartlarının geliştirilmesini kolaylaştırmalı, hemşirelerin beklentilerini karşılamalı ve aktif katılımlarını desteklemelidir (12). Hizmet içi sürekli eğitim programlarının içeriğinde yaşlı bireylerin özelliklerini ve bakım süreçlerini içeren eğitimlerin yer alması gerekmektedir. Geleneksel öğretim yöntemlerinin yerine teknolojinin sağladığı yeni olanaklardan yararlanılarak oluşturulmuş çağdaş öğretim yöntemlerinden biri olan simülasyon ile eğitimin hizmet içi eğitim programında yer alması, sağlık kurum ve kuruluşlarında simülasyona dayalı eğitime yönelik politika ve prosedürlerin geliştirilmesine katk1 sağlayacaktır $(13,14)$.

Hemşirelerin güvenli ve kontrollü bir ortamda öğrenmesine izin veren simülasyon uygulamaları ile mesleki temel eğitimin yanında hizmet içi eğitimlerle yeterliliğin geliştirilmesinin, yaşlı bireylere yönelik bakım gereksinimlerinin belirlenmesi, bakımlarının planlanması ve uygulanması süreçlerine katkı sağlayacağ düşünülmektedir.

Literatürde hemşirelerin yaşlı bakımında yetkinliklerinin arttırılmasında kullanılan eğitim yöntemleri üzerine yapılan çalışmalar sınırlıdır. Hemşirelik lisans eğitiminde öğrencilere yönelik farklı alanlarda simülasyon uygulamaları yapılmış ve literatürde konuya yönelik çok sayıda araştırma yapıldığ görülmüştür. Ancak alanda çalışan hemşirelerin hizmet içi eğitimde simülasyon temelli eğitimin yeteri kadar yer almadığı ve araştırmaların yetersiz olduğu görülmektedir. $\mathrm{Bu}$ bağlamda çalışma, yaşlı bakımında hemşirelerin yetkinliğini arttıran eğitim yöntemlerine yönelik çalışmaları analiz etmek ve araştırmacılara somut veri sunmak amacıyla planlanmıştır.

\section{GEREÇ VE YÖNTEMLER}

Çalışma, Mart-Ekim 2020 tarihleri arasında, Sağlık Bilimleri Üniversitesi elektronik veri tabanları, "Türk Tıp Dizini", "ULAKBİM", "Pubmed", "Google Scholar", "Science Direct" ve "Networked Digital Library of Theses and Dissertations" taranarak 350 makaleye ulaşılmıştır. Literatür incelemesinde; "simülasyon", "hemşirelik" ve "yaşlı" anahtar kelimeleri Türkçe ve İngilizce olarak son on yılda yayınlanmış (2010-2020), yayın dili Türkçe ya da İngilizce olan, tam metni bulunan makaleler seçilmiştir. Araştırmada yüksek lisans ve doktora tezleri, araştırma özetleri, araştırmanın tam metinleri, hemşirelik dergileri 
ve yardımc1 dergilerde yer alan veriler dahil edilmiştir. Çalışma kapsamında incelenen 350 araştırmadan inceleme dişında tutulma kriterleri dikkate alındığında; 333 çalışma tam metnine ulaşılamaması, yayının son 10 y1l içerisinde yapılmış olmaması, yayın dilinin belirlenen diller içerisinde yer almaması ve orijinal araştırma makalesi olmaması nedeniyle örneklem dışı bırakılmıştır. Sonuç olarak; yaşlı bireylerin bakımında hemşirelik yetkinliğinin arttırılmasına yönelik eğitim yöntemleri konusunda yapılmış ve tam metne sahip olan toplam 17 çalışma incelemeye alınmıştır. Çalışma kapsamına dahil edilen makalelerin seçiminde aşağıdaki kriterler dikkate alınmıştır;

- Hemşirelikte yaşlı bireylerin bakımına yönelik eğitimde simülasyon kullanımının değerlendirilmesi,

- $\mathrm{Bu}$ araştırmaların verilerinin toplanmasinda standardize hasta simülasyon yöntemi, video simülasyon, insan/hasta simülatörleri, gerçekliğe yakınlığı yüksek/orta insan simülatörleri, bilgisayar temelli simülasyon yöntemlerinin kullanılması,

- Klinik bakımda yer alan hemşirelere ve öğrenci hemşirelere odaklanan araştırma olması,

- Yayın dilinin Türkçe ya da İngilizce olmas1,

- Son on yılda yayınlanmış (2010-2020) olmas1,

- Tam metnine ulaşılabilmesi.

Sistematik inceleme kapsamında araştırmalar yazar adı ve yılı, araştırmanın amacı, araştırma tasarımı, örneklem büyüklüğü, bağımlı değişkenler, bulgular ve kavramsal çerçeve şeklinde düzenlenerek Tablo I'de özetlenmiştir.

Çalışmada kapsamlı literatür taraması yapılmış olmakla birlikte geçerli sonuçlar içeren makalelere ulaşılamama ihtimali bir sınırlılık oluşturmuş olabilir.

\section{BULGULAR}

$\mathrm{Bu}$ sistematik inceleme çalışmasında, 20102020 yılları arasında yayınlanan 17 çalışma yer almaktadır. İncelenen araştırmaların yedisi ön test-son test düzeninde yarı deneysel, üçü randomize kontrollü, ikisi yarı deneysel, ikisi nitel tanımlayıcı, biri kalitatif araştırma, biri karma yöntem ve biri tanımlayıcı çalışmadır. İncelenen araştırmaların özetleri Tablo I'de yer almaktadır. Çalışmalarda toplam 1834 katılımcı yer almıştır. Araştırmaya dahil edilen 2 çalışma klinikte bakım veren hemşireler, 15 çalışma ise hemşirelik öğrencileri ile gerçekleştirilmiştir. Klinikte bakım veren hemşireler ile yapılan çalışmalar, hemşirelerin yaşlı bireylerin bakımına yönelik eğitimde simülasyon deneyimi, tutumu ve istekliliği incelenirken; öğrenciler ile yapılan çalışmalarda ise bilgi, beceri, tutum, farkındalık, empati, bakım motivasyonu, klinik yarg1, öğrenme deneyimi, simülasyon deneyimi, klinik karar verme becerisi incelenmiştir.

Sistematik inceleme kapsamında; klinikte bakım veren hemşireler ile yapılan iki çalışmada da hemşirelere yaşlı bireylerin özelliklerine özgü simülasyonu sağlayan kıyafetlerin giydirildiği, üç ay sonra değerlendirme yapıldığı ve simülasyon uygulamasının yaşlı bireylere yönelik bakım kalitesinin arttırılmasında etkili olduğu bulunmuştur $(5,11)$. Lee ve arkadaşlarının 2016 yılında yaptığı çalışmada hemşirelerde simülasyon uygulaması sonrası yaşlı bireylere yönelik bakımda tutum ve istekliliğin olumlu yönde arttığı bildirilmiştir. Bowden ve arkadaşlarının 2020 yılında yaptığı çalışmada ise örneklem sayısının diğer araştırmalara göre daha az olduğu bildirilmiştir $(9,15)$.

Hemşirelik öğrencileri ile gerçekleştirilen çalışmalardan her ikisinin de örneklem sayısının 275 olup, incelemeye dahil edilen çalışmalar içinde en yüksek örneklem olduğu görülmüştür $(16,17)$. İki çalışmada klinik karar verme durumunu belirlemek amaciyla yapılmıştır. Diğer iki çalışmada da 
Bandura'nın Gözlemsel Öğrenme ve Tanner'ın Klinik Yarg1 Modeli kuramsal çerçeve olarak benimsemiştir $(16,17)$. Johnson ve arkadaşları tarafından yapılan çalışmada öğrencilerin simüle geriatrik bireyin bakımına yönelik fark etme, yorumlama ve yanttlama üzerine klinik yargı boyutları anlamlı bulunmuştur (16). Lasater ve arkadaşlarının çalışmasında ise yaşlı bireyin perioperatif bakımına yönelik simülasyon ve gerçek hayat deneyiminin faydalı olduğu bulunmuştur (17).

İnceleme kapsamında hemşirelik öğrencileri ile yapılan çalışmalardan altısı yaşlılara yönelik tutumu, üçü yaşlı bireylere yönelik empatiyi incelerken ikisinin ise yaşlı bireylere yönelik simülasyon deneyiminin etkilerini değerlendirdiği dikkati çekmektedir. Yaşlı bireylere yönelik planlanan simülasyon eğitimleri sonrası tutumu değerlendiren çalışmalarda tutumun istatistiksel olarak anlamlı düzeyde arttığı belirlenmiştir (18-23). Hemşirelik öğrencilerinde empatik yaklaşımı değerlendiren çalışmalarda verilerin istatistiksel olarak anlamlı bulunduğu, simülasyona dayalı eğitimin empatik yaklaşımı ve hasta merkezli bakımı desteklediği görülmüştür (24-26).

İnceleme kapsamındaki yaşlı bireylerin anlaşılmasına yönelik tasarlanan iki çalışmada, hemşirelik öğrencilerinin simülasyon deneyimi değerlendirilmiştir. Bu çalışmalarda hemşirelik öğrencilerinin simülasyon deneyimine yönelik olumlu sonuçlar elde edilmiştir $(27,28)$.

İncelemede Kwon ve arkadaşları tarafindan yapılan hemşirelik öğrencilerinin geriatrik acil durumları öğrenmeleri için geliştirilen simülasyon uygulamasının klinik karar verme becerisini arttırdığı bulunmuştur (29). Diğer bir çalışma da hasta devir teslim sürecini işleyen geriatrik simülasyon uygulamasının öğrencilerin öğrenme deneyimleri üzerine etkisi incelenmiş ve simülasyon uygulamasının hasta devir teslim sürecini öğrenmede etkili olduğu bulunmuştur (30).
Sistematik inceleme sonucunda araştırmalar eğitim girişimleri açısından ele alındığında; araştırmaların altısında yaşlılık hissi oluşturan simülatörler tercih edilmiştir $(9,15,19,22,23,26)$. İncelenen çalışmaların üçünde orta ve yüksek derecede gerçekliğe yakın insan simülatörleri ile araştırma bulguları elde edilmiştir (16,25,27). Araştırmaların dördünde ise standardize hasta simülasyonu kullanılmıştır $(20,21,28,30)$. Diğer araştırmalarda ise rol yapma, bilgisayar tabanlı simülasyon, video simülasyon, vaka çalışması gibi yöntemlerle simülasyon uygulama bulguları elde edilmiştir $(17,18,24,29)$. 
Tablo I. Literatürde incelenen araştırmaların veri analizi

\begin{tabular}{|c|c|c|c|c|c|c|}
\hline Yazar ve Yll & Amaç & $\begin{array}{l}\text { Araştırma } \\
\text { Tasarımı }\end{array}$ & $\begin{array}{l}\text { Örneklem } \\
\text { Büyüklüğg̈ü }\end{array}$ & $\begin{array}{l}\text { Bağımlı } \\
\text { Değișkenler }\end{array}$ & Bulgular & \begin{tabular}{|l|} 
Kuramsal \\
Cerçeve
\end{tabular} \\
\hline $\begin{array}{l}\text { Yu ve Chen } \\
(2012)\end{array}$ & $\begin{array}{l}\text { Yaşlı Simülasyon Programının, hemşirelik } \\
\text { lise ve yüksekokul mezunu hemşirelerin } \\
\text { yaşli bireylere karşı tutumları } \\
\text { ve bakım evlerindeki yaşlilara bakım verme } \\
\text { motivasyonu üzerindeki } \\
\begin{array}{ll}\text { değerlendirilmesi } & \text { etkilerinin }\end{array}\end{array}$ & $\begin{array}{l}\text { Ön test - son } \\
\text { test, deney- } \\
\text { kontrol gruplu } \\
\text { yarı deneysel }\end{array}$ & 83 & $\begin{array}{l}\text { Bakım } \\
\text { motivasyonu } \\
\text { ve tutum }\end{array}$ & $\begin{array}{l}\text { Simülasyon } \\
\text { uygulanmasından dört hafta sonra, } \\
\text { deney grubu katılımcılarının yaşli } \\
\text { yetişkinlere yönelik olumlu tutum } \\
\text { geliştirdiği ve bakım motivasyonunu } \\
\text { artırdığ1 görülmüştür. }\end{array}$ & Belirtilmemiş \\
\hline $\begin{array}{l}\text { Johnson ve } \\
\text { ark. } \\
(2012)\end{array}$ & $\begin{array}{l}\text { Hemşirelik öğrencilerinin rol modellemesi } \\
\text { ile kalça kırığı olan simüle geriatrik bireyin } \\
\text { bakımına yönelik klinik karar verme } \\
\text { etkisinin belirlenmesi }\end{array}$ & $\begin{array}{l}\text { Deney - } \\
\text { kontrol gruplu } \\
\text { yarı deneysel }\end{array}$ & 275 & $\begin{array}{l}\text { Klinik karar } \\
\text { verme }\end{array}$ & $\begin{array}{l}\text { Rol model videosu izletilerek ve } \\
\text { gerçekliğe yakınlığ1 yüksek insan } \\
\text { simülatörü ile üç aşamalı simülasyon } \\
\text { uygulamasına katılan ögrencilerin } \\
\text { simülasyon sırasinda çekilen videoları } \\
\text { üzerinden gözlemciler tarafindan } \\
\text { toplanan verilerde öğrencilerin fark } \\
\text { etme, yorumlama ve yanıtlama } \\
\text { üzerine klinik karar verme boyutları } \\
\text { anlamlı bulunmuştur. }\end{array}$ & $\begin{array}{l}\text { Bandura } \\
\text { (Gözlemsel } \\
\text { ögrenme ) } \\
\text { Tanner (Klinik } \\
\text { Yarg1 Modeli) }\end{array}$ \\
\hline $\begin{array}{l}\text { Smith ve } \\
\text { Barry } \\
(2013)\end{array}$ & $\begin{array}{l}\text { Yaşlı bireylere bakım veren toplum sağliğ } 1 \\
\text { hemşireliği öğrencileri için geriatrik bireyin } \\
\text { evde bakımına yönelik simülasyon } \\
\text { deneyiminin sonuçlarının incelenmesi }\end{array}$ & Yar1 deneysel & 56 & $\begin{array}{l}\text { Simülasyon } \\
\text { deneyimi }\end{array}$ & 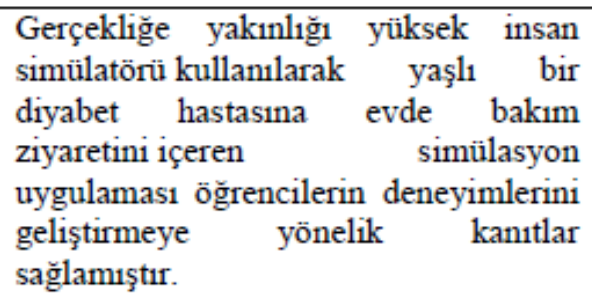 & Belirtilmemiş \\
\hline $\begin{array}{l}\text { Lasater ve ark. } \\
\text { (2014) }\end{array}$ & $\begin{array}{l}\text { Yaşlı bireyde perioperatif bakım süreçlerine } \\
\text { yönelik simülasyon uygulamasının klinik } \\
\text { karar verme üzerine etkisinin belirlenmesi }\end{array}$ & $\begin{array}{l}\text { Deney-kontrol } \\
\text { gruplu } \\
\text { karma yöntem }\end{array}$ & 275 & $\begin{array}{l}\text { Klinik karar } \\
\text { verme }\end{array}$ & $\begin{array}{l}\text { Simülasyon uygulamasından dört hafta } \\
\text { sonra, katılımcilar gerçek hayattaki, } \\
\text { yaşlı perioperatif hastalara bakım } \\
\text { vermiştir. Simüle hasta ve gerçek } \\
\text { hayattaki bakım deneyimlerinden } \\
\text { sonra, ögrencilerin klinik karar verme } \\
\text { üzerine olumlu etkileri olduğu } \\
\text { bulunmuştur. }\end{array}$ & $\begin{array}{l}\text { Bandura } \\
\text { (Gözlemsel } \\
\text { ögrenme) } \\
\text { Tanner (Klinik } \\
\text { Yarg1 Modeli) }\end{array}$ \\
\hline
\end{tabular}


Tablo I. Literatürde incelenen araştırmaların veri analizi (devamı)

\begin{tabular}{|c|c|c|c|c|c|c|}
\hline Yazar ve Yll & Amaç & $\begin{array}{l}\text { Araştırma } \\
\text { Tasarımı }\end{array}$ & $\begin{array}{l}\text { Örneklem } \\
\text { Büyüklüŭg̈ü }\end{array}$ & $\begin{array}{l}\text { Bağımlı } \\
\text { Değiskenler }\end{array}$ & Bulgular & $\begin{array}{l}\text { Kuramsal } \\
\text { Cerceve }\end{array}$ \\
\hline $\begin{array}{l}\text { Chen ve ark. } \\
\text { (2014) }\end{array}$ & $\begin{array}{l}\text { Geriatrik İlaç Oyunu simülasyon } \\
\text { uygulamasinnı hemşirelik ögrencilerinin } \\
\text { yaşl bireylere yönelik empati, tutum ve } \\
\text { hasta deneyimleri üzerine etkisinin } \\
\text { incelenmesi }\end{array}$ & $\begin{array}{l}\text { Ön test- son test } \\
\text { yar1 deneysel }\end{array}$ & 58 & $\begin{array}{l}\text { Empati, tutum } \\
\text { ve hasta } \\
\text { deneyimi }\end{array}$ & $\begin{array}{l}\text { Öğrenciler, üç saatlik Geriatrik İlaç } \\
\text { Oyunu simülasyon } \\
\text { uygulaması sırasında yaşlı bir } \\
\text { bireyin rolünü oynamıştır. Ögrenciler } \\
\text { yaşlanmaya bağlı değişiklikleri } \\
\text { kendileri yaşamadan önce, yaşli } \\
\text { bireylerin duygu ve deneyimlerinden } \\
\text { haberdar olmadıklarını ve simülasyon } \\
\text { uygulamalarının öğrenci eğitimi } \\
\text { surasında yaşli bireylere yönelik } \\
\text { empati ve tutum düzeyini ele almak } \\
\text { için yararlı olduğu tespit edilmiştir. }\end{array}$ & Belirtilmemiş \\
\hline $\begin{array}{l}\text { Lee ve ark. } \\
(2016)\end{array}$ & $\begin{array}{l}\text { Yaşlanma simülasyonu programının } \\
\text { hemşirelerin yaşli bakımına yönelik tutum } \\
\text { ve isteklerinin iyileştirmedeki etkinliğinin } \\
\text { değerlendirmesi }\end{array}$ & Yar1 deneysel & 134 & $\begin{array}{l}\text { Tutum } \\
\text { isteklilik }\end{array}$ & 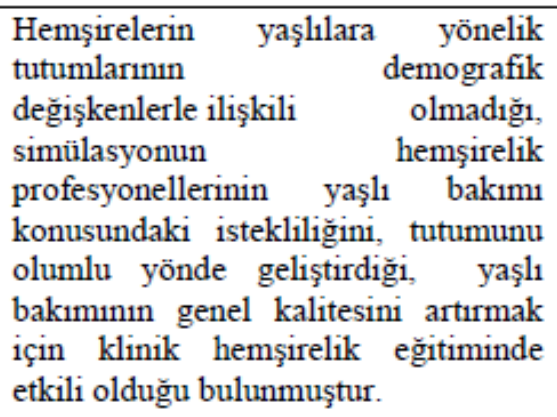 & Belirtilmemiş \\
\hline $\begin{array}{l}\text { Haley ve ark. } \\
(2017)\end{array}$ & $\begin{array}{l}\text { Yaşlı bireylerde bakım mükemmeliyetini } \\
\text { sağlama üzerine geliş̧tirilmiş simülasyon } \\
\text { uygulamasının hemşirelik öğrencisinin } \\
\text { aktif dinleme, öz farkındalık ve empati } \\
\text { geliştirme üzerine etkisinin belirlenmesi }\end{array}$ & $\begin{array}{l}\text { Randomize } \\
\text { kontrollü }\end{array}$ & 50 & $\begin{array}{l}\text { Aktif dinleme, } \\
\text { öz farkındalik } \\
\text { ve empati }\end{array}$ & $\begin{array}{l}\text { Simülasyon uygulaması sonrası dört } \\
\text { haftalık takipte anlamlı farklilik } \\
\text { gözlenmiş olup yaşlilar için Gelişmiş } \\
\text { Bakım Mükemmeliyeti Simülasyon } \\
\text { Senaryosunun kullanmasının empati, } \\
\text { hasta merkezli bakım, öz bilinç ve } \\
\text { aktif empatik dinlemeyi iyileştirmede } \\
\text { etkili olduğu tespit edilmiştir. }\end{array}$ & $\begin{array}{l}\text { Rogers } \\
\text { (Hasta Merkezli } \\
\text { Bakım Teorisi) }\end{array}$ \\
\hline
\end{tabular}


Tablo I. Literatürde incelenen araştırmaların veri analizi (devamı)

\begin{tabular}{|c|c|c|c|c|c|c|}
\hline Yazar ve Yll & Amaç & $\begin{array}{l}\text { Araştırma } \\
\text { Tasarımı }\end{array}$ & $\begin{array}{l}\text { Örneklem } \\
\text { Büyülklüğü }\end{array}$ & $\begin{array}{l}\text { Bağımlı } \\
\text { Değișkenler }\end{array}$ & Bulgular & $\begin{array}{l}\text { Kuramsal } \\
\text { Cerçeve }\end{array}$ \\
\hline $\begin{array}{l}\text { Macaden ve } \\
\text { ark. } \\
(2017)\end{array}$ & $\begin{array}{l}\text { Yaşlı bireylerde duyusal bozukluklara } \\
\text { yönelik ögrenci hemşireler tarafindan } \\
\text { farkındalığı arttırılması ve yaşl bireye } \\
\text { yönelik empati geliştirilmesinde } \\
\text { simülasyon ile eğitimin etkisinin } \\
\text { belirlenmesi }\end{array}$ & $\begin{array}{l}\text { Kalitatif, odak } \\
\text { grup görüşmesi }\end{array}$ & 125 & $\begin{array}{l}\text { Farkındalik, } \\
\text { duygusal } \\
\text { deneyim ve } \\
\text { empati }\end{array}$ & 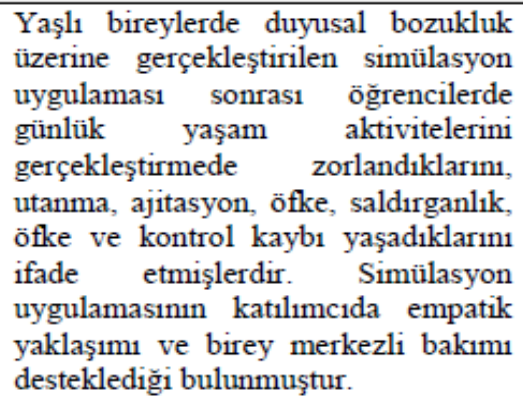 & $\begin{array}{l}\text { Kolb } \\
\text { (Deneyimsel } \\
\text { Ögrenme } \\
\text { Teorisi) } \\
\text { Tanner } \\
\text { (Klinik Yarg1 } \\
\text { Modeli) }\end{array}$ \\
\hline $\begin{array}{l}\text { Maharaj } \\
(2017)\end{array}$ & $\begin{array}{l}\text { Hemşirelik öğrencilerinin Alzheimer } \\
\text { hastalığ olan yaşlı bireylere yönelik } \\
\text { tutumlarının geliştirilmesinde canlı model } \\
\text { simülasyonunun } \\
\text { değerlendirilmesi }\end{array}$ & $\begin{array}{l}\text { Randomize } \\
\text { kontrollü }\end{array}$ & 65 & Tutum & $\begin{array}{l}\text { Canlı model simülasyonlarının } \\
\text { hemşirelik ögrencilerinin Alzheimer } \\
\text { Hastalığ1 olan yaşlı birey hakkında } \\
\text { bilgilerini arttırmalarını sağladığı, son } \\
\text { test sonuçlarının olumlu yönde } \\
\text { anlamlı olduğu bulunmuştur. }\end{array}$ & $\begin{array}{l}\text { Mezirow } \\
\text { (Dönüştürücü } \\
\text { Öğrenme } \\
\text { Teorisi) }\end{array}$ \\
\hline $\begin{array}{l}\text { Skinner } \\
(2017)\end{array}$ & 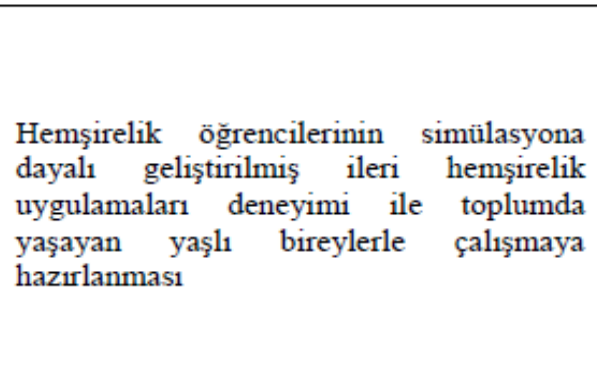 & $\begin{array}{l}\text { Ön test-son test, } \\
\text { yarı deneysel }\end{array}$ & 21 & $\begin{array}{l}\text { Simülasyon } \\
\text { deneyimi }\end{array}$ & $\begin{array}{l}\text { Simülasyon uygulaması sonrasında } \\
\text { ögrencilerin ön test ve son test } \\
\text { puanlarında önemli farkların } \\
\text { bulunmadığ1 ancak yaşli bireylerin } \\
\text { fiziksel } \\
\text { sosyalleşme ve yaşlilara yönelik bilgi } \\
\text { kazandikları, simülasyonun yaşli } \\
\text { sağlığına yönelik toplum sağlığ1 } \\
\text { eğitimine entegre edilmesinin } \\
\text { gerekliliği bulunmuştur. }\end{array}$ & Belirtilmemiş \\
\hline $\begin{array}{l}\text { Kwon ve ark. } \\
(2018)\end{array}$ & $\begin{array}{l}\text { Hemşirelik ögrencilerinin geriatrik acil } \\
\text { durumlar için geliştirilmiş bilgisayar } \\
\text { tabanlı simülasyon ile klinik karar verme } \\
\text { becerilerinin geliştirmesi }\end{array}$ & Tanımlayıc1 & 88 & $\begin{array}{l}\text { Klinik karar } \\
\text { verme becerisi }\end{array}$ & 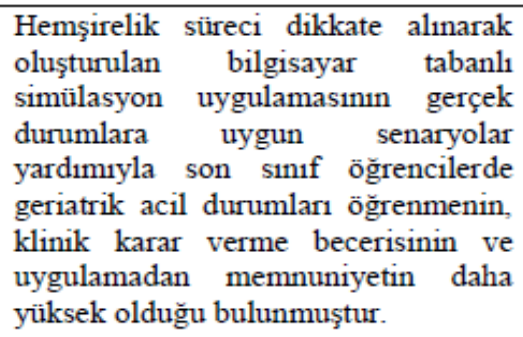 & $\begin{array}{l}\text { Probleme } \\
\text { Dayalı Ögrenme }\end{array}$ \\
\hline
\end{tabular}


Tablo I. Literatürde incelenen araştırmaların veri analizi (devamı)

\begin{tabular}{|c|c|c|c|c|c|c|}
\hline $\begin{array}{l}\text { Yazar ve } \\
\text { Yll }\end{array}$ & Amaç & $\begin{array}{l}\text { Araştırma } \\
\text { Tasarımı }\end{array}$ & $\begin{array}{l}\text { Örneklem } \\
\text { Büyüklüğg̈ü }\end{array}$ & $\begin{array}{l}\text { Bağımlı } \\
\text { Değișkenler }\end{array}$ & Bulgular & $\begin{array}{l}\text { Kuramsal } \\
\text { Cerçeve }\end{array}$ \\
\hline $\begin{array}{l}\text { Fernandes } \\
\text { ve ark. } \\
(2019)\end{array}$ & $\begin{array}{l}\text { "Yaşlanma Hemşireliği Oyunu" isimli } \\
\text { simülasyon uygulamasının } \\
\text { ögremşirelik } \\
\text { tutumlarina etkisinin değerlendirilmesi }\end{array}$ & $\begin{array}{l}\text { Ön test-son test, } \\
\text { yarı deneysel }\end{array}$ & 45 & Tutum & $\begin{array}{l}\text { Simülasyon uygulaması sonrası yaşli } \\
\text { bireylere yönelik tutumun önemli } \\
\text { ölçüde iyileştiği, ön test ve son test } \\
\text { uygulaması karşılaştırıldığında } \\
\text { simülasyon oyununun yaşlı bireylere } \\
\text { yönelik tutumun geliştirilmesinde } \\
\text { önemli olduğu bulunmuştur. }\end{array}$ & Belirtilmemiş \\
\hline $\begin{array}{l}\text { Eide ve ark. } \\
(2020)\end{array}$ & $\begin{array}{l}\text { Hemşirelik birinci sinıf ögrencilerinin } \\
\text { klinik hasta devri uygulaması (ISBAR) } \\
\text { süreçlerini içeren geriatrik hasta } \\
\text { simülasyonu uygulaması sonrası sahip } \\
\text { oldukları ögrenme deneyimlerinin } \\
\text { sentezlenmesi ve değerlendirilmesi }\end{array}$ & Nitel tanımlayıcı & 216 & $\begin{array}{l}\text { Öğrenme } \\
\text { Deneyimi }\end{array}$ & $\begin{array}{l}\text { Öğrenme deneyimlerinin analizinde, } \\
\text { klinik hasta devri uygulaması (ISBAR) } \\
\text { süreçlerini içeren geriatrik hasta } \\
\text { simülasyonu, ögrenciler için yaşlı } \\
\text { hastalarla klinik deneyime başlamadan } \\
\text { önce değerli bir araç olduğu } \\
\text { bulunmuştur. }\end{array}$ & Belirtilmemiş \\
\hline $\begin{array}{l}\text { Cheng ve } \\
\text { ark. } \\
(2020)\end{array}$ & $\begin{array}{l}80 \text { yaşındaki bir kişinin fizyolojik } \\
\text { deneyimlerini taklit etmeye odaklanan, } \\
\text { Senior Simulation Suit Programının } \\
\text { (SSSP) hemşirelik öğrencilerinin yaşli } \\
\text { yetişkin bakımına yönelik olumlu tutum } \\
\text { geliştirmesinin değerlendirilmesi }\end{array}$ & $\begin{array}{l}\text { Randomize } \\
\text { kontrollü }\end{array}$ & 139 & $\begin{array}{l}\text { Olumlu } \\
\text { Tutum }\end{array}$ & $\begin{array}{l}\text { Deney grubuna SSSP simülasyonu için } \\
\text { plasebo kıyafetler ve kontrol grubuna } \\
\text { yaşlilığ taklit eden kyafetler } \\
\text { giydirilmiştir. Arasında anlamlı bir fark } \\
\text { bulunmamıştır. Her iki grupta da } \\
\text { olumlu tutum gerçekleşmiştir. }\end{array}$ & Belirtilmemiş \\
\hline $\begin{array}{l}\text { Torkshavand } \\
\text { ve ark. } \\
(2020)\end{array}$ & $\begin{array}{l}\text { Hemşirelik öğrencilerinin yaşlı hastalara } \\
\text { eğitim vermede bilgi, beceri ve } \\
\text { tutumlarının geliştirilmesinde simülasyon } \\
\text { temelli ögrenmenin etkilerinin } \\
\text { belirlenmesi }\end{array}$ & $\begin{array}{l}\text { Ön test-son test } \\
\text { deney-kontrol } \\
\text { gruplu, yar1 } \\
\text { deneysel }\end{array}$ & 70 & $\begin{array}{l}\text { Bilgi, beceri } \\
\text { ve tutum }\end{array}$ & $\begin{array}{l}\text { Deney ve kontrol grubundaki tüm } \\
\text { öğrenciler zamanla yaşlı hasta eğitimi } \\
\text { bilgi ve becerilerinde iyileşme } \\
\text { gösterdiği ve simülasyon temelli eğitim } \\
\text { alan ögrencilerde daha kalıcı } \\
\text { gelişmeler olduğu bulunmuştur. }\end{array}$ & $\begin{array}{l}\text { Kolb } \\
\text { (Deneyimsel } \\
\text { Ögrenme } \\
\text { Teorisi) }\end{array}$ \\
\hline
\end{tabular}


Geriatrik Bilimler Dergisi / Journal of Geriatric Science 2021; 4 (1): 23-34

Şendir M. ve ark. Yaşlı Bireyin Bakımı ve Hemşirelik

Tablo I. Literatürde incelenen araştırmaların veri analizi (devamı)

\begin{tabular}{|c|c|c|c|c|c|c|}
\hline Yazar ve Yll & Amaç & $\begin{array}{l}\text { Araştırma } \\
\text { Tasarımı }\end{array}$ & $\begin{array}{l}\text { Örneklem } \\
\text { Büyüklüğg̈ }\end{array}$ & $\begin{array}{l}\text { Bağımlı } \\
\text { Değișkenler }\end{array}$ & Bulgular & $\begin{array}{l}\text { Kuramsal } \\
\text { Çerçeve }\end{array}$ \\
\hline $\begin{array}{l}\text { Bowden ve ark. } \\
(2020)\end{array}$ & $\begin{array}{l}\text { Yaşlanma giysisi simülasyon } \\
\text { uygulaması sonrası yaşli bireylere } \\
\text { bakım veren hemşirelerinin } \\
\text { düşüncelerinin ve deneyimlerinin } \\
\text { keşfedilmesi }\end{array}$ & Nitel tanımlayıc1 & 15 & $\begin{array}{l}\text { Simülasyon } \\
\text { Deneyimi }\end{array}$ & $\begin{array}{l}\text { Simülasyon uygulaması sonrası } \\
\text { hemşirelerin gerçek hissetmesi, anlayış } \\
\text { geliştirme ve kendimi değiştirme } \\
\text { düşüncesinde oldukları, uygumananın } \\
\text { yaşlanmanın zorlukları hakkında içgörü } \\
\text { kazandırdığ1 ve bireyselleştirilmiş } \\
\text { uygulamalarında değişiklikler yapması } \\
\text { için umut verici yenilikçi bir eğitim } \\
\text { yaklaşımı olduğu ortaya çıkmıştır. }\end{array}$ & $\begin{array}{l}\text { Kolb } \\
\text { (Deneyimsel } \\
\text { ögrenme } \\
\text { teorisi) } \\
\text { NLN } \\
\text { (Jeffries } \\
\text { Simulation } \\
\text { Framework) }\end{array}$ \\
\hline $\begin{array}{l}\text { Demirtaş ve Başak } \\
(2020)\end{array}$ & $\begin{array}{lr}\text { Hemşirelik } & \text { birinci } \\
\text { öğrencilerinin } & \text { yaşlı bireylere } \\
\text { yönelik tutumlarına günlük yaşam } \\
\text { aktiviteleri } & \text { simülasyonunun } \\
\text { etkisinin değerlendirilmesi }\end{array}$ & $\begin{array}{l}\text { Ön test-son test, } \\
\text { yar1 deneysel }\end{array}$ & 119 & Tutum & $\begin{array}{l}\text { Günlük yaşam } \quad \begin{array}{r}\text { aktiviteleri } \\
\text { simülasyonunun, }\end{array} \text { hemşirelik } \\
\text { öğrencilerinin yaşlı bireylere yönelik } \\
\text { olumlu tutumlarını geliştirmede etkili } \\
\text { bir yöntem olduğu tespit } \\
\text { edilmiştir. Katılımcı geri bildirimleri, } \\
\text { simülasyonun empati ve geriatri } \\
\text { hemşireliğinin farkındalığını artırdığını } \\
\text { göstermiştir. }\end{array}$ & Belirtilmemiş \\
\hline
\end{tabular}




\section{TARTIŞMA}

Sistematik inceleme sonucunda; incelenen makaleler, yaşlı bireylerin bakım süreçlerini içeren simülasyon temelli eğitimlerle, klinikte bakım veren hemşirelerin ve hemşirelik öğrencilerinin yaşlı bireylere yönelik olumlu tutum geliştirmesine katkı sağladığını göstermektedir (15,18-23). Dünya ve Türkiye'deki demografik değişim süreci göz önüne alındığında hemşirelik öğrencilerinin, lisans eğitimlerinde ve klinikte bakım veren hemşirelerin hizmet içi eğitimlerinde yaşlı bireylerin bakım süreçlerine yönelik simülasyon temelli eğitimi içine alan bir eğitim programının uygulanması, yaşlı bireylere yönelik olumlu tutum geliştirilmesine katk1 sağlayacağı düşünülmektedir.

İncelenen araştırmalarda; orta ve yüksek derecede gerçekliğe yakın insan simülatörleri, yaşl1lık hissi oluşturan simülasyon kıyafetleri ve rol yapma gibi farklı eğitim girişimleri ile uygulanan simülasyonların hemşirelik öğrencilerinin, yaşlı bireylere yönelik birey merkezli bakımını desteklediği ve empatik yaklaşımını arttırdığını göstermektedir (24-26). Yaşlı bireylerin bakımının gerçekleştirildiği ortamlarda, hemşirelerin yaşlı bireylere yönelik riski değerlendirip yönetmesinin, empatik yaklaşımı benimsemesinin ve birey merkezli bakımı sunmasının, güvenli bir ortamda öğrenmeye izin veren farklı simülasyon yöntemlerini içeren eğitim programları ile mümkün olacağ düşünülmektedir.

Araştırma sonuçları incelendiğinde; yaşlı bireyler ile klinik deneyime başlamadan önce eğitim programlarında simülasyon uygulamalarına yer verilmesi ile klinik bilgi ve karar verme becerisinin arttığ görülmektedir $(21,29)$. Yaşlı bireylere yönelik tasarlanmış simülasyon temelli eğitimler ile hemşirelerin bilgi ve becerilerinin geliştirilmesinin yanında klinik alanda bilgiyi kullanarak karar vermesinde simülasyon uygulamalarının yerinin zaman ile artacağ 1 ve teorik bilgi ile uygulama arasındaki boşluğun dolacağı düşünülmektedir.

İnceleme bulgularında, yaşlı bireylere yönelik simülasyon uygulamalarının daha çok hemşirelik öğrencileri üzerinde gerçekleştirildiği, alanda aktif bakım gerçekleştiren hemşireler üzerine yapılan araştırmaların sayısının oldukça az olduğu görülmektedir $(\mathrm{n}=2, \% 11,7)$. Hemşirelerin yaşlı bireylerin bakım süreçlerini içeren hizmet içi eğitim programlarında, geleneksel öğretim yöntemlerinin yerine teknolojinin sağladığı yeni olanaklardan yararlanılarak oluşturulmuş çağdaş öğretim yöntemlerinin kullanılmasının etkin öğrenmeyi sağlamak için önemli olduğu ve bu konuda ileriki yillarda yapilacak çalışmaların bu boşluğu kapatacağ düşünülmektedir.

İnceleme sonuçları, yaşlı bireylere yönelik tasarlanmış simülasyon uygulamalarının hemşirelik eğitim programlarına entegre edilmesinin, hemşirelerde yaşlı bireylere yönelik bireyselleştirilmiş bakım uygulamalarını desteklediği, isteklilik ve tutum düzeylerini olumlu yönde geliştirdiği, hemşirelik öğrencilerinde ise yaşlı bireylere yönelik olumlu tutum, empatik yaklaşım, bakım motivasyonu, bilgi, beceri ve klinik deneyim öncesi yargılamayı güçlendirdiğini göstermektedir.

\section{SONUÇ}

Literatür incelemesinde, Dünya'da ve Türkiye'de görülen demografik değişiklikler göz önüne alınmış ve yaşlı bireylerin bakımını üstlenen hemşirelerin yetkinliklerinin arttırılmasında simülasyon uygulamalarının önemli olduğu sonucuna ulaşılmıştır. Simülasyon uygulamaları hem uluslararası alanda hem de ülkemiz literatüründe güncel yaklaşımlardan biri olarak yer almasına rağmen yaşlı bireyin bakımına yönelik becerilerinin güçlendirilmesinde hemşirelikte hizmet içi eğitim programlarında kullanılması 
ile ilgili kanıtların sınırlı olduğu görülmektedir. Hemşirelerin çalışma ortamlarından uzaklaşmadan, hizmet içi eğitim programında bakım becerilerinin güçlendirilmesine yönelik geliştirilmiş simülasyon uygulamasına imkân verilmesi, bu konuda akademisyen ve alanda çalışan hemşirelerin iş birliği ile donanımlı hemşirelerin yetiştirilmesine katkı sağlanacaktır. Gerek hizmet içi eğitim programlarında gerekse hemşirelik lisans eğitimlerinde yaşlı bireylerin bakımına yönelik simülasyon uygulamalarını içine alan eğitim programlarının yer alması, sağlık kurumlarında sayısı giderek artan yaşlı bireylere yönelik bakımın kalitesini arttıracağı ve maliyetlerin kontrol altına alınarak yaşlı sağlığına yönelik yeni politika ve prosedürlerin geliştirilmesine yardımcı olacağı düşünülmektedir. Ülkemizde hemşirelik hizmet içi ve lisans eğitimlerinde yaşlı bireylere yönelik tasarlanmış simülasyon uygulamalarına ilişkin çalışmaların yetersiz olduğu ve bu sistematik araştırmanın konuya ilişkin sonraki birçok araştırma için destek oluşturacağı, daha fazla araştırmanın yapılmasina gereksinim olduğu öngörülmektedir.

\section{Çıkar Çatışması ve Fonlama}

Yazı için finansal destek alınmamıştır.

Yazarlar çıkar çatışması olmadığını belirtir.

\section{Yazarların Makaleye Katkıları}

Çalışma konsepti ve tasarımı: RE, MŞ; Veri toplama: RE; Veri analizi ve yorumlama: RE, MŞ; Yazı taslağı: RE; İçeriğin eleştirel incelenmesi: MŞ; Son onay ve sorumluluk: RE, MŞ.

\section{KAYNAKLAR}

1. Kalınkara V. Temel Gerontoloji Yaşlılık Bilimi. 3. Baskı, Ankara, Nobel Tıp Kitabevi, 2016, 102-115.

2. Akgün Çıtak E. Yaşlılık ve İletişim. Editörler; Bilgili N, Kitiş Y. Yaşlılık ve Yaşılı Sağlığı. 1. Baskı, Ankara, Vize Yayıncılik, 2017, 512-521.

3. The World Health Organization Report 1998. http://www.who.int/whr/1998/en/whr98_en.pdf. Erişim Tarihi: 20.07.2019
4. United Nations (UN), Department of Economic and Social Affairs Population Division. (2017), "World Population Prospects: The 2017 Revision Key Findings and Advance Tables. Working Paper No. ESA/P/WP/248.

5. Türkiye İstatistik Kurumu (TÜIKK), İstatistiklerle Türkiye 2015. Yayın No. 4431, https://biruni.tuik.gov.tr/yayin/views/visitorPages/yayinGo runtuleme.zul?yayin_no=358, Erișim Tarihi: 20.12 .2020

6. Türkiye İstatistik Kurumu (TÜIK), İstatistiklerle Türkiye 2016. Yayın No. 4473, https://biruni.tuik.gov.tr/yayin/views/visitorPages/yayinGo runtuleme.zul?yayin_no=399, Erişim Tarihi: 20.12.2020

7. Türkiye İstatistik Kurumu (TÜİK), (2018a), Haber Bülteni: Nüfus Projeksiyonları, 2018-2080. https://tuikweb.tuik.gov.tr/PreHaberBultenleri.do?id=3056 7, Erișim Tarihi: 20.12.2020

8. Samancı Tekin Ç, Kara, F. Dünyada ve Türkiye'de Yaşlılık. Uluslararası Bilimsel Araştırma Dergisi, 2018; 3(1): 219-229.

9. Bowden A, Wilson V, Traynor V, Chang HR. Exploring the use of ageing simulation to enable nurses to gain insight into what it is like to be an older person. Journal of Clinical Nursing, 2020; 29(23-24): 4561-4572.

10. Savaş S, Akçiçek F. Kapsamlı geriatrik değerlendirme. Ege Tıp Dergisi, 2010; 49(3): 19- 30.

11. Kaya D, Koçyiğit SE, Dokuzlar Ö ve ark. Geriatri poliklinik olgularında geriatrik sendromlar: 1048 olgunun analizi. Ege Tıp Dergisi, 2018; 57(1): 31-35.

12. Chaghari M, Saffari M, Ebadi A, Ameryoun A. Empowering education: A new model for in-service training of nursing staff. Journal of Advances In Medical Education \& Professionalism, 2017; 5(1):26.

13. Acaroğlu R, Şendir M. Bireyselleștirilmiș bakımı değerlendirme skalaları. İstanbul Üniversitesi Florence Nigtingale Hemşirelik Dergisi, 2012; 20(1):10-16. ISSN 1304-4869.

14. Smith MB, Macieira TGR, Bumbach MD et al. The use of simulation to teach nursing students and clinicians palliative care and end-of-life communication: a systematic review. Am J Hosp Palliat Care, 2018; 35(8):1140-1154.

15. Lee $\mathrm{C}-\mathrm{H}$, Hsu H-C, Lee $\mathrm{C}-\mathrm{H}$. Effects of aging simulation program on nurses' attitudes and willingness toward elder care. Taiwan Geriatr Gerontol, 2016; 11(2): 105-115.

16. Johnson EA, Lasater K, Hodson-Carlton K et al. Geriatrics in simulation: role modeling and clinical judgment effect. Nurs Educ Perspec, 2012; 33 (3): 176-180.

17. Lasater K, Johnson EA, Ravert P, Rink D. Role modeling clinical judgment for an unfolding older adult simulation. $\mathrm{J}$ Nurs Educ, 2014; 53(5):257-264.

18. Fernandes CSNN, Couto G, Afonso A. An aging simulation game's impact on the attitudes of nursing students. Nurs Pract Today, 2019; 6(3):142-151.

19. Yu CY, Chen KM. Experiencing simulated aging improves knowledge of and attitudes toward aging. J Am Geriatr Soc, 2012; 60(5):957-961.

20. Maharaj T. Live-model simulation: improving nursing students' attitudes and knowledge of alzheimer's disease. Clinical Simulation in Nursing, 2017; 13(9), 446-451.

21. Torkshavanda G, Khatiban M, Soltanian AR. Simulationbased learning to enhance students' knowledge and skills in educating older patients. Nurse Educ Pract, 2020; 42: 102678.

22. Cheng WLS, Ma PK, Lamb YY. et al. Effects of senior simulation suit programme on nursing students' attitudes towards older adults: a randomized controlled trial. Nurse Educ Today, 2020; 88:104330.

23. Demirtas A, Basak T. Daily life activities simulation: Improving nursing students' attitudes toward older patients. Jpn J Nurs Sci, 2020; 18(1):e12375

24. Chen, AMH, Kiersma ME, Yehle KS, Plake KS. Impact of the Geriatric Medication Game ${ }^{\circledR}$ on nursing students' empathy and attitudes toward older adults, Nurse Educ Today, 2014; 35(1), 38-43.

25. Haley B, Heo S, Wright $P$ et al. Effects of using an advancing care excellence for seniors simulation scenario 
on nursing student empathy: a randomized controlled trial. Clinical Simulation in Nursing, 2017; 13: 511-519.

26. Macaden L, Smith A, Croy S. Simulation on sensory impairment in older adults: nursing education. Br J Nurs, 2017; 26(19): 1057- 1064.

27. Smith S, Barry D. An innovative approach to preparing nursing students for care of the elderly in the home. Geriatr Nurs, 2013; 34(1):30-34.

28. Skinner, HM. Simulation: Preparing nursing students to work with community-dwelling older adults. Clinical Simulation in Nursing, 2017; 13(10):520-523.
29. Kwon DY, Lee SJ, Kim YC et al. A computer-based clinical simulation system based on constructivist learning environments for undergraduate nursing students in the field of geriatric emergencies. International Journal of Pure and Applied Mathematics, 2018; 118(24). ISSN: 1314-3395 (online version).

30. Eide WM, Johansson L, Eide LSP. FIRST-YEAR nursing students' experiences of simulation involving care of older patients. A descriptive and exploratory study. Nurs Educ Pract, 2020; 45: 102797. 